\title{
FACTORS AFFECTING THE INCIDENCE OF HYPERURICEMIA ON THE REJANG TRIBE IN BENGKULU
}

\author{
Jumiyati $^{1}$, Tetes Wahyu Witradharma ${ }^{1}$ \\ ${ }^{1}$ Jurusan Gizi, Poltekes Kemenkes Bengkulu, Indonesia \\ Email: yatijumi70@yahoo.co.id
}

Submitted: $25^{\text {th }}$ March 2020; Accepted: $10^{\text {th }}$ June 2020

https://doi.org/10.36525/sanitas.2020.5

\begin{abstract}
The Rejang tribe is partly living on the lowland and coastal coastline, the typical Rejang cooking tradition has been assimilated into the Minang and Malay cooking traditions. Malay people like to consume foods that are fatty, dining, oily and salty. Fish, beef, shrimp and nuts have purine content of 9-100 $\mathrm{mg}$ of purin/100 $\mathrm{g}$ of foodstuffs. One of the factors affecting hyperuricemia is the habit of consuming purine eating, it will result in gout disease. The purpose of this research is to determine the factors that influence the incidence of hyperuricemia on the Rejang tribe in Bengkulu. Design research is cross sectional. Rejang Group's research samples numbered 64 respondents. Data collected is the result of uric acid examination, gender, age, knowledge, consumption pattern, liquid consumption, BMI. The instruments used are questionnaires, eating consumption patterns using FFQ form, weight gained by weighing with digital scales. Data analysis using Chi-Square and multivariate tests using logistic regression test
\end{abstract}

Keywords: age, gender, consumption patterns, knowledge, liquid consumption, BMI

This is an open access journal, and articles are distributed under the terms of the Creative Commons Attribution-Non Commercial-Share Alike 4.0 License, which allows others to remix, tweak, and build upon the work non-commercially, as long as appropriate credit is given and the new creations are licensed under the identical terms.

(C)2020 Sanitas 


\title{
FAKTOR-FAKTOR YANG MEMPENGARUHI KEJADIAN HIPERURISEMIA PADA SUKU REJANG DI KOTA BENGKULU
}

\begin{abstract}
ABSTRAK
Suku Rejang sebagian kecil tinggal di dataran rendah dan pesisir pantai, Tradisi memasak khas Rejang telah berasimilasi dengan tradisi memasak orang Minang dan Melayu. Masyarakat Melayu suka mengkonsumsi jenis makanan yang berlemak, bersantan, berminyak dan asin. Ikan, daging sapi, udang dan kacang memiliki kadar purin 9-100 mg puri/100 g bahan makanan. Salah satu faktor mempengaruhi hiperurisemia adalah kebiasaan mengkonsumsi makan mengandung purin, hal ini akan mengakibatkan penyakit gout. Tujuan penelitian ini untuk mengetahui faktor-faktor yang mempengaruhi kejadian hiperurisemia pada Suku Rejang yang ada di Kota Bengkulu. Desain penelitian adalah cross sectional. Sampel penelitian kelompok Suku Rejang berjumlah 64 responden. Data yang dikumpulkan adalah hasil pemeriksaan asam urat, jenis kelamin, umur, pengetahuan, pola konsumsi, konsumsi cairan, IMT. Instrumen yang digunakan berupa kuesioner, pola konsumsi makan menggunakan form FFQ, berat badan didapatkan dengan cara penimbangan dengan timbangan digital. Analisis data menggunakan uji Chi-Square dan multivariat menggunakan uji Regresi Logistik.
\end{abstract}

Kata kunci: Umur, jenis kelamin, pola konsumsi, pengetahuan, konsumsi cairan, IMT.

\section{PENDAHULUAN}

Masyarakat Suku Rejang sebagian kecil tinggal di dataran rendah dan pesisir pantai, suku asli Rejang menempati wilayah Provinsi Bengkulu. Masyarakat suku Rejang sekarang ini sudah banyak berpindah baik di kota maupun pesisir. Tradisi memasak khas Rejang telah berasimilasi dengan tradisi memasak orang Minang dan orang-orang Melayu yang bertetangga dengan orang Rejang. ${ }^{1}$ Masyarakat Melayu suka mengkonsumsi jenis makanan yang berlemak, bersantan, berminyak dan asin. Jenis masakan Melayu seperti tumis belacan, pais ikan asin, tauco, pindang ikan laut, rendang, palai udang, gulai siput, kacang. ${ }^{2}$ Ikan, daging sapi, udang dan kacang memiliki kadar purin 9-100 mg puri/100 g bahan makanan. ${ }^{3}$

Salah satu faktor yang mempengaruhi hiperurisemia adalah kebiasaan mengkonsumsi bahan pangan yang mengandung purin. Purin merupakan protein yang termasuk dalam golongan nucleoprotein, tubuh manusia memproduksi purin sekitar 75\% yang diproduksi oleh ginjal, dan sisanya berasal dari makanan yang dikonsumsi. Konsumsi makanan yang mengandung purin tinggi dapat menyebabkan ginjal kesulitan untuk mengeluarkan kelebihan asam urat di dalam tubuh sehingga dapat menyebabkan terjadinya penumpukan kristal asam urat pada area persendian. ${ }^{4}$ Seseorang akan beresiko dikatakan menderita asam urat jika kadar asam urat dalam darah di atas $7 \mathrm{mg} / \mathrm{dl}$ laki-laki dan di atas $6 \mathrm{mg} / \mathrm{dl}$ pada wanita. ${ }^{5}$ 
Faktor resiko kejadian hiperurisemia selain kebiasaan mengkonsumsi makanan mengandung purin dapat disebabkan oleh usia, minum alkohol, kegemukan, hipertensi dan gangguan fungsi ginjal. Purin diproduksi oleh tubuh secara alami karena purin merupakan salah satu elemen penting pembentuk rantai DNA dan RNA dalam tubuh. Kebutuhan purin dari asupan 15\% dari total kebutuhan, yaitu purin dalam bahan makanan merupakan hasil dari metabolisme protein. ${ }^{6}$ Asam urat dihasilkan dari pemecahan dan sisa pembuangan dari bahan makanan tertentu yang mengandung nukleotida purin yang diproduksi tubuh. Tingginya kadar asam urat di dalam darah penderita gout disebabkan banyaknya sisa-sisa pembuangan hasil metabolism purin, sedangkan eksresi asam urat melalui urin terlalu sedikit. ${ }^{4}$

Gout mempengaruhi lebih dari 1\% orang dewasa di AS, dan radang sendi yang paling umum terjadi di kalangan pria. Peningkatan prevalensi asam urat yang berpotensi disebabkan oleh perubahan pola makan dan gaya hidup. Faktor risiko kejadian asam urat ada dua yaitu yang tidak dapat dimodifikasi dan dimodifikasi. Faktor risiko yang tidak dapat dimodifikasi termasuk usia dan jenis kelamin. Prevalensi asam urat meningkat dalam hubungan langsung dengan usia, usia di negara-negara industri dapat berkontribusi pada prevalensi asam urat yang lebih tinggi melalui hubungan gangguan dengan penyakit terkait penuaan seperti sindrom metabolik dan hipertensi. ${ }^{7}$

Prevalensi dan insidensi gout meningkat di Korea tahun 2007 dan 2015. Pria lebih tua memiliki prevalensi dan insidensi gout yang lebih tinggi dibandingkan dengan wanita dan populasi yang lebih muda. Prevalensi dan kejadian gout diprediksi menggunakan analisis deret waktu, prevalensi gout meningkat dari 3,49 (3,48-3,51) per 1000 orang pada 2007 menjadi $7,58(7,55-7,60)$ per 1000 orang pada 2015. Insiden gout adalah 1,52 (1,51-1,53) ) pada tahun 2009 dan meningkat menjadi 1,94 $(1,93-1,95)$ per 1.000 orang pada tahun 2015. Perkiraan prevalensi dan insiden gout (95\% CI) pada tahun 2025 adalah 16,59 (15,85-17,34) per 1000 orang dan 3,81 $(3,14-4,47)$ per 1000 orang. $^{8}$

Penelitian yang dilakukan di Kin-Hu didapatkan hasil hiperurisemia laki-laki lebih banyak yaitu $25,8 \%$ dan perempuan $15,0 \% .^{9}$ survei yang dilakukan di kota Qingdao, Cina secara acak dan berturut-turut hasil yang di dapat terjadi peningkatan prevalensi asam urat dari 3,6/1000 pada tahun 2002 menjadi 5,3/1000 pada tahun 2004. ${ }^{10}$ 
Berdasarkan hasil Riset Kesehatan Dasar (Riskesdas) Indonesia tahun 2013, prevalensi penyakit sendi adalah $11,9 \%$ dan prevalensi penyakit sendi berdasarkan diagnosis atau gejala sebesar $24,7 \%$. Di Indonesia, asam urat menduduki urutan kedua setelah osteoartritis. ${ }^{11}$ Berdasarkan data yang diperoleh dari Profil Dinkes Kota Bengkulu Radang sendi merupakan penyakit nomor empat terbanyak diderita oleh masyarakat Bengkulu setelah penyakit kulit alergi. Prevalensi penderita radang sendi di Kota Bengkulu pada tahun 2016 adalah sebanyak 9.031 jiwa. ${ }^{12}$

Meskipun prevalensi terjadi peningkatan, namun nyeri sendi dengan latar belakang hiperurisemia masih menjadi masalah serius karena manifestasinya tidak hanya terbatas pada sendi, tapi juga menimbulkan gangguan fungsi ginjal, jantung, dan mata. ${ }^{13}$

\section{METODE PENELITIAN}

Penelitian ini menggunakan desain deskriptif analitik dengan pendekatan cross sectional. Populasi dalam penelitian ini adalah seluruh masyarakat Rejang yang mengikuti perkumpulan Rejang yang ada di Kota Bengkulu, besar sampel adalah 64 orang. Teknik pengambilan sampel menggunakan simpel random sampling. Data yang dikumpulkan dari sampel adalah hasil pemeriksaan asam urat, jenis kelamin, umur, pengetahuan, pola konsumsi, konsumsi cairan, IMT. Instrumen yang digunakan berupa kuesioner, pola konsumsi makan menggunakan form FFQ, berat badan didapatkan dengan cara penimbangan dengan timbangan digital. Analisis data menggunakan uji Chi-Square dan multivariat menggunakan uji Regresi Logistik. ${ }^{14}$

Tabel 1. Gambaran karakteristik sampel

\begin{tabular}{|c|c|c|}
\hline Karakteristik Responden & $\mathrm{f}$ & $\%$ \\
\hline \multicolumn{3}{|l|}{ Jenis Kelamin } \\
\hline 1. Perempuan & 41 & 64.1 \\
\hline 2. Laki-laki & 23 & 35.9 \\
\hline \multicolumn{3}{|l|}{ Umur } \\
\hline 1. $\leq 50$ tahun & 33 & 48.4 \\
\hline 2. $>50$ tahun & 31 & 51.6 \\
\hline
\end{tabular}

\section{HASIL DAN PEMBAHASAN}

Berdasarkan tabel 1, menunjukkan bahwa $64,1 \%$ responden berjenis kelamin perempuan dan 35,9\% berjenis kelamin laki-laki dengan kategori umur $<50$ tahun 
$48,4 \%$ dan $>50$ tahun $51,6 \%$. Sedangkan untuk kategori yang berpendidikan tinggi sebanyak $20,6 \%$ dan berpendidikan rendah sebanyak 79,4\%.

Tabel 2. Gambaran variabel sampel

\begin{tabular}{rrr}
\hline \multicolumn{1}{c}{ Variabel } & $\mathrm{f}$ & $\%$ \\
\hline Pengetahuan & & \\
1. $\quad$ Baik & 53 & 82.8 \\
2. Kurang & 11 & 17.2 \\
\hline Pola Konsumsi & & \\
1. $\quad$ Sering & 37 & 57.8 \\
2. Jarang & 27 & 42.2 \\
\hline Konsumsi Cairan & & \\
1. Baik & 11 & 17.2 \\
2. Kurang Baik & 53 & 82.8 \\
\hline IMT $\quad$ Normal & 22 & 34.4 \\
1. & 42 & 65.6 \\
\hline Kejadian Hiperurisemia & & \\
1. Nomar & 35 & 54.7 \\
2. Hiperurisemia & 29 & 45.3 \\
\hline
\end{tabular}

Berdasarkan tabel 2, untuk kategori berpengetahuan yang baik sebanyak $82,8 \%$ dan yang kurang 17,2\%. Pada pola konsumsi sering sebanyak 20,6\% dan pola konsumsi jarang 79,4\%. Pada konsumsi cairan sebanyak 17,2\% sebagai kategori baik dan $82,8 \%$ di kategori konsumsi cairan yang kurang baik. Pada pengukuran IMT yang normal sebanyak 34,4\% dan tidak normal 65,6\%. Pada riwayat keluarga sebanyak 26,6\% tidak ada keturunan dan 73,4\% ada keturunan. Sedangkan hasil pengukuran untuk kadar asam urat yang normal sebanyak 54,7\% dan hiperurisemia sebanyak $45,3 \%$.

Hasil analisis hubungan antara umur dengan kejadian hiperurisemia diperoleh yang berumur $>50$ tahun sebanyak 12 (38,7\%) tidak hiperurisemia dan 19 (61,3\%) mengalami hiperurisemia, ada hubungan signifikan antara umur dengan kejadian asam urat. Jenis kelamin laki-laki sebanyak $5(21,7 \%)$ yang tidak hiperurisemia dan $18(78,3 \%)$ mengalami hiperurisemia, ada hubungan yang signifikan antara jenis kelamin dengan kejadian asam urat. Sedangkan responden berpengetahuan kurang sebanyak 8 (72,7\%) tidak hiperurisemia dan 3 (27,3\%) mengalami hiperurisemia, tidak ada hubungan signifikan antara pengetahuan dengan kejadian asam urat. Responden dengan pola konsumsi sering sebanyak 4 (14,8\%) tidak hiperurisemia dan $23(85,2 \%)$ mengalami hiperurisemia, ada hubungan signifikan antara pola konsumsi dengan kejadian asam urat. Untuk responden yang mengkonsumsi cairan secara baik 
sebanyak 7(63,6\%) tidak hiperurisemia dan 4 (36,4\%) mengalami hiperurisemia, tidak ada hubungan signifikan antara konsumsi cairan dengan kejadian asam urat. Pengukuran IMT diperoleh IMT tidak normal sebanyak $23 \quad(54,8 \%)$ tidak hiperurisemia dan $19(45,2 \%)$ mengalami hiperurisemia, tidak ada hubungan signifikan antara IMT dengan kejadian asam urat.

Tabel 3. Distribusi sampel berdasarkan faktor resiko kejadian hiperurisemia

\begin{tabular}{|c|c|c|c|c|c|c|c|c|}
\hline \multirow{3}{*}{ Faktor Kejadian } & \multirow{3}{*}{ Kategori } & \multicolumn{4}{|c|}{ Kejadian Hiperurisemia } & \multirow{2}{*}{\multicolumn{2}{|c|}{ Total }} & \multirow{3}{*}{ p-value } \\
\hline & & \multicolumn{2}{|c|}{ Tidak } & \multicolumn{2}{|c|}{$\mathrm{Ya}$} & & & \\
\hline & & $\mathrm{f}$ & $\%$ & $\mathrm{~F}$ & $\%$ & $\mathrm{~F}$ & $\%$ & \\
\hline \multirow[t]{2}{*}{ Umur } & $\leq 50$ tahun & 23 & 69,7 & 10 & 30,3 & 33 & 100 & \multirow[b]{2}{*}{0,025} \\
\hline & $>50$ tahun & 12 & 38,7 & 19 & 61,3 & 31 & 100 & \\
\hline \multirow[t]{2}{*}{ Jenis Kelamin } & Perempuan & 30 & 73,2 & 11 & 26,8 & 41 & 100 & \multirow[b]{2}{*}{0,001} \\
\hline & Laki-laki & 5 & 21,7 & 18 & 78,3 & 23 & 100 & \\
\hline \multirow[t]{2}{*}{ Pengetahuan } & Baik & 27 & 50,9 & 26 & 49,1 & 53 & 100 & \multirow[b]{2}{*}{0,319} \\
\hline & Kurang & 8 & 72,7 & 3 & 27,3 & 11 & 100 & \\
\hline \multirow[t]{2}{*}{ Pola Konsumsi } & Jarang & 31 & 83,8 & 6 & 16,2 & 37 & 100 & \multirow[b]{2}{*}{0,000} \\
\hline & Sering & 4 & 14,8 & 23 & 85,2 & 27 & 100 & \\
\hline \multirow[t]{2}{*}{ konsumsi Cairan } & Baik & 7 & 63,6 & 4 & 36,4 & 11 & 100 & \multirow[b]{2}{*}{0,741} \\
\hline & Tidak & 28 & 52,8 & 25 & 47,2 & 53 & 100 & \\
\hline \multirow[t]{2}{*}{ IMT } & Normal Tidak & 12 & 54,5 & 10 & 45,5 & 22 & 100 & \multirow{2}{*}{0,987} \\
\hline & Normal & 23 & 54,8 & 19 & 45,2 & 42 & 100 & \\
\hline
\end{tabular}

Hasil analisis dapat disimpulkan bahwa dari keseluruhan variabel independen yang diduga mempengaruhi kadar asam urat pada Suku Rejang yaitu pola konsumsi bahan makanan yang mengandung purin terhadap kadar asam urat dengan nilai $p$ value 0,000. Nilai OR yang diperoleh yaitu 0,032 artinya pola konsumsi bahan makanan yang mengandung purin mempunyai peluang 0,032 kali menyebabkan peningkatan kadar asam urat.

\section{PEMBAHASAN}

\section{Umur}

Hasil penelitian menunjukkan sebagian besar responden berusia di bawah 50 tahun $(51,6 \%)$, terdapat hubungan antara umur dengan kejadian hiperurisemia pada Suku Rejang. Usia merupakan salah satu faktor resiko penyakit asam urat, hal ini berkaitan dengan adanya peningkatan kadar asam urat seiring dengan bertambahnya usia. ${ }^{15}$ Meskipun kejadian hiperurisemia bisa terjadi pada semua tingkat usia namun 
kejadian ini meningkat pada laki - laki dewasa berusia $\geq 30$ tahun dan wanita setelah menopause atau berusia $\geq 50$ tahun, karena pada usia ini wanita mengalami gangguan produksi hormon estrogen. ${ }^{16}$

Tabel 4. Hasil akhir analisis Multivariat

\begin{tabular}{|l|l|l|l|}
\hline Variabel & $P$ & OR & $95 \%$ CI \\
\hline Umur & 0,021 & 7,854 & $0,570-29,864$ \\
Jenis Kelamin & 0,004 & 0,065 & $0,015-0,554$ \\
Pola konsumsi & 0,000 & 0,032 & $0,002-0,176$ \\
\hline
\end{tabular}

Sesuai dengan penelitian usia dikonfirmasi sebagai faktor risiko yang signifikan untuk hiperurisemia, prevalensi hiperurisemia meningkat dari usia 60 tahun, dan mencapai setelah usia 70 tahun. ${ }^{17}$ Prevalensi hiperurisemia meningkat dari 3,5\% berusia 45-49 tahun menjadi $10,3 \%$ berusia 70 tahun. Prevalensi hiperurisemia lebih besar di daerah perkotaan $(8,0 \%)$ daripada di daerah pedesaan $(5,0 \%) .{ }^{18}$

\section{Jenis Kelamin}

Hasil penelitian menunjukkan responden berjenis kelamin laki-laki sebesar $35,9 \%$, ada hubungan antara jenis kelamin dengan kejadian hiperurisemia pada Suku Rejang ( $\mathrm{p}=0.000$ ). Jenis kelamin merupakan salah satu faktor resiko penyebab asam urat. Laki-laki memiliki resiko mengalami hiperurisemia lebih besar daripada perempuan, karena secara umum laki-laki memiliki kadar asam urat dalam darah lebih tinggi dari pada perempuan dan laki-laki tidak memiliki hormone esterogen hal ini yang menyebabkan penyakit asam urat lebih sering menyerang laki-laki. ${ }^{15}$ Sedangkan hasil penelitian menyatakan jenis kelamin laki-laki beresiko 2 kali lipat mengalami hiperurisemia. ${ }^{19}$ di Korea Prevalensi asam urat yang mengunjungi Pusat Pemeriksaan Kesehatan sebesar $16,6 \%$ pria dan $6,7 \%$ untuk wanita. Faktor yang terkait hiperurisemia yaitu jenis kelamin dan konsumsi alkohol. ${ }^{20}$

\section{Pengetahuan}

Hasil penelitian menunjukkan sebagian besar responden berpengetahuan baik $82,8 \%$, tidak terdapat hubungan antara pengetahuan dengan kejadian hiperurisemia pada Suku Rejang ( $\mathrm{p}=0.319$ ). Pengetahuan merupakan hasil dari tahu, dan ini terjadi setelah seseorang melakukan penginderaan terhadap suatu objek tertentu. Penginderaan terjadi melalui pancaindera manusia, yakni indra penglihatan, 
pendengaran, penciuman, rasa dan raba. Sebagian besar pengetahuan manusia diperoleh melalui mata dan telinga. Pengetahuan merupakan domain yang sangat penting dalam membentuk tindakan seseorang, untuk mempermudah penerimaan informasi oleh sasaran (menurut penelitian para ahli) indra yang paling banyak menyalurkan pengetahuan ke dalam otak adalah mata kurang lebih 75\% sampai $87 \%$ dari pengetahuan manusia, sedangkan 13\% sampai $25 \%$ lainya tersalurkan melalui indra yang lain. ${ }^{21}$ Berbeda dengan hasil penelitian yang dilakukan di Puskesmas Ranotana Weru di dapatkan hasil terdapat hubungan signifikan antara tingkat pengetahuan dengan kadar asam urat dalam darah. ${ }^{22}$

\section{Konsumsi Cairan}

Hasil uji statistik tidak terdapat hubungan yang bermakna antara konsumsi cairan dengan kejadian hiperurisemia pada Suku Rejang. Namun berdasarkan hasil penelitian ditemukan 25 responden $(47,2 \%)$ yang hiperurisemia dengan konsumsi cairan tidak normal. Pada penelitian ini ada keterbatasan pada saat me-recall asupan cairan, asupan cairan yang ditanya hanya berdasar dari minuman (air putih, susu, kopi, teh). Sementara cairan dari bahan makanan dan buah-buahan tidak diambil. Menurut Guyton air yang berasal dari makanan sudah diteliti menghasilkan $870 \mathrm{ml} .^{23}$

Hasil penelitian di Cimahi pada kelompok kedua riwayat hiperurisemia keluarga tidak berpengaruh pada hubungan asupan cairan, asupan cairan yang kurang meningkatkan risiko 6,92 kali terkena hiperurisemia. ${ }^{24}$ Begitu juga hasil penelitian pada Suku Bali didapatkan asupan yang kurang tidak berdampak terhadap kadar asam urat. ${ }^{25}$ Hasil penelitian di Semarang menyatakan bahwa tidak ada hubungan antara konsumsi cairan dengan kadar asam urat. ${ }^{26}$ Hasil tersebut sejalan dengan teori bahwa cairan merupakan salah satu media pembuangan hasil metabolit tubuh, termasuk asam urat. Jika seseorang mengkonsumsi cairan dalam jumlah tinggi, reabsorbsi air di ginjal menurun dan eksresi zat terlarut air meningkat. ${ }^{27}$

\section{IMT (Indeks Massa Tubuh)}

Hasil uji statistik tidak terdapat hubungan yang bermakna antara indeks masa tubuh dengan kejadian hiperurisemia pada Suku Rejang. Namun berdasarkan hasil penelitian ditemukan 19 responden dengan hiperurisemia memiliki IMT tidak normal. Hal ini sesuai dengan hasil penelitian sebelumnya yang menunjukan bahwa gout atau 
timbulnya kristal-kristal Monosodium Urate (MSU) yang dipicu hiperurisemia pada sendi dan jaringan banyak ditemukan pada penderita dengan kelebihan berat badan. Seiring terjadinya peningkatan berat badan maka sekresi asam urat akan meningkat sementara ekskresinya akan menurun. ${ }^{19}$

Hasil penelitian di Kendari bahwa responden usia 45-54 tahun yang memiliki indeks massa tubuh (IMT) kurang baik, memiliki risiko menderita rematik sebesar 8,34 kali, jika dibandingkan dengan responden yang memiliki indeks Massa Tubuh baik. $^{28}$

\section{Pola Konsumsi}

Hasil penelitian menunjukan sebagian besar responden pola konsumsi bahan makanan yang mengandung purin yaitu $42,2 \%$, terdapat hubungan antara pola konsumsi dengan kejadian hiperurisemia pada Suku Rejang $(p=0,000)$ dengan nilai OR yang diperoleh yaitu 0,032 artinya pola konsumsi bahan makanan yang mengandung purin mempunyai peluang 0,032 kali menyebabkan peningkatan kadar asam urat. Adapun Jenis bahan pangan yang dikonsumsi masyarakat suku Rejang yang tinggal di Kota Bengkulu berupa jeroan, daging sapi, udan, ikan, kangkung, lemah (makanan khas Rejang Lebong terbuat dari bambu yang difermentasi). Pola makan merupakan tingkah laku responden atau sekelompok orang dalam memenuhi kebutuhan akan makan yang meliputi sikap, kepercayaan, budaya, sosial dan pilihan makanan. Kebudayaan suatu masyarakat mempunyai kekuatan yang cukup besar untuk mempengaruhi seseorang dalam memilih dan mengolah pangan yang akan dikonsumsi dan Pola makan seseorang dapat dilihat melalui jumlah, frekuensi, jenis, fungsi, dan cara pengolahan makan tersebut. ${ }^{29}$

Hasil penelitian ini sejalan dengan penelitian yang dilakukan di Dusun Pondok, terdapat hubungan yang cukup signifikan antara pola makan dengan penyakit gout dengan koefisien korelasi ( $\rho$ ): 0,483 dan nilai p: 0,049, Semakin sering mengkonsumsi makan dengan kadar purin yang tinggi maka semakin tinggi urit acid. ${ }^{30}$ Begitu juga hasil penelitian yang dilakukan di Jombang ada hubungan pola makan dengan kadar asam urat pada pra-lansia. ${ }^{31}$ 


\section{SIMPULAN}

Dari beberapa faktor analisis kejadian asam urat yang berhubungan adalah umur merupakan faktor risiko 7,85 kali terkena asam urat, jenis kelamin merupakan faktor resiko 0,06 terhadap kejadian asam urat begitu juga pola konsumsi 0,03 terkena asam urat.

Disarankan untuk penderita hiperurisemia atau asam urat untuk memilih makanan dengan sumber purin rendah yang dapat dimakan setiap hari, seperti nasi, ubi, singkong, roti, mie, bihun,susu, keju, telur, sayuran (sawi, bunga kol, selada, wartel dan lain-lain) serta buah-buahan.

\section{DAFTAR PUSTAKA}

1. "Paguyuban Masyarakat Rejang Lebong se-Jabodetabek Gelar Halal Bihalal, Panitia Sajikan Lemea". Diakses tanggal 2019-11-22.

2. Lembaga Adat Riau. (2010). Masakan Khas Melayu Riau. Bidang Pemberdayaan Perempuan Dewan Pimpinan Harian.

3. Sunita Almatsier,2005. Penuntun diet, Gramedia Pustaka Utama, Jakarta.

4. Diah Krisnatuti, dkk. 2001. Perencanaan Menu untuk Penderita Gangguan Asam Urat, Jakarta. Penebar Swadaya.

5. Wijayakusuma,2008. Ramuan Lengkap Herbal Taklukkan Penyakit. Jakarta: Pustaka Bunda

6. Suriana, Neti. 2014. Herbal Sakti Atasi Asam Urat. Mutiara; Jakarta

7. Kenneth G Saag, Hyon Choi, 2006. Epidemiology risk factors and lifestyle modifications for gout. Volume 8 ISSN: 1478-6362. DOI.https://doi.org/10.1186/ar1907.https://arthritisresearch.biomedcentral.co $\mathrm{m} /$ articles/10.1186/ar1907).

8. Ji-Won Kim, Sang Gyu Kwak, Hwajeong Lee, Seong-Kyu Kim, JungYoon Choe, Sung-Hoon Park Prevalence and incidence of gout in Korea: data from the national health claims database 2007-2015. September 2017, Volume 37, Issue 9, pp 1499-1506 https://link.springer.com/article/10.1007/s00296-017-3768-4

9. Lin KC, Lin H, Chou P.2000. Community Based Epidemiological Study on Hyperuricemia and Gout in Kin-Hu, Kimen. J Rheumatology. Diakses 13 Desember 2018. 
10. Miao Z, Li C, Chen Y, Zhao S, Wang Y, Wang Z, Chen X, Xu F, Wang F, Sun R, Hu J, Song W, Yan S, Wang C. Dietary and lifestyle changes associated with high prevalence of hyperuricaemia and gout in the Shandong coastal cities of Eastern China. J Rheumatol. 2008;35:1859-1864

11. Kementerian Kesehatan Republik Indonesia. 2013. Riset Kesehatan Dasar. Diakses pada tanggal 07 Februari 2018 ; www. depkes. go.id

12. Propil Dinas Kesehatan Bengkulu

13. Misnadiarly. 2014. Mengenal Penyakit Artritis. [internet]. 2008 Januari 18]. Tersedia di: http:jurnal.unej.ac.id.index/php/articl e/view/2606/2434

14. Notoatmojo S. 2010. Metodologi Penelitian Kesehatan. Jakarta: PT Rineka Cipta.

15. Sari. Yanita NI \& Nur Syamsiyah. 2017. Berdamai Dengan Asam Urat.Cetakan pertama. Jakarta : Bumi Medika. Hal 1-30

16. Misnadiarly. 2014. Mengenal Penyakit Artritis. [internet]. 2008 [disitansi 2014 Januari 18]. Tersedia di: http:jurnal.unej.ac.id.index/php/articl e/view/2606/2434

17. Kuo, C.-F., Grainge, M. J., Zhang, W. \& Doherty, M. Global epidemiology of gout: prevalence, incidence and risk factors. Nature reviews rheumatology $\mathbf{1 1}$, 649-662 (2015)

18. Peige Song, He Wang, Wei Xia, Xinlei Chang, Manli Wang, Lin An. Prevalence and correlates of hyperuricemia in the middle-aged and older adults in China. SCiENtifiC RePortS | (2018) 8:4314 | DOI:10.1038/s41598018-22570-9.https://www.nature.com/srep.

19. Poletto, J. et al. 2011. Hyperuricemia and Associated Factor : A CrossSectional Study of Japanese-Brazilians. Cad. saude Publica, 27(2):369-378.

20. Kim EH, Jeon K, Park KW, Kim HJ, Ahn JK, Jeon CH, Cha H-S, Koh E-M (2004) The prevalence of gout among hyperuricemic population (the prevalence of gout among hyperuricemic population). J Rheum Dis 11(1):713

21. Notoatmodjo. Pengantar Pendidikan Kesehatan dan Ilmu Perilaku. Yongyakarta.2003

22. Anisha M.G Songgigilan, Inneke Rumengan, Rina Kundre, Hubungan Pola Makan Dan Tingkat Pengetahuan Dengan Kadar Asam Urat Dalam Darah Jumiyati, Tetes Wahyu Witradharma $\mid 63$ 
Pada Penderita Gout Artritis Di Puskesmas Ranotana Weru, e-journal Keperawatan(e-Kp) Volume 7 Nomor 1, Mei 2019. Diakses November 2018

23. Guyton AC, Fisiologi Kedokteran. Jakarta: EGC, 1993

24. Nelly Olifa Ilyas, et al, Beberapa Faktor Yang Berhubungan Dengan Kejadian Hiperurisemia pada Pasien Rawat Jalan Di RS Dustria Cimahi, Jurnal Gizi Indonesia 2014, 37(2):91-100

25. Hensen-Tjokorda Raka Putra, Hubungan Konsumsi Purin dengan Hiperurisemia pada Suku Bali di Daerah Pariwisata Pedesaan. Jurnal Penyakit Dalam, 2007:8(1):37-43

26. Diantari, E. dan A. C. Pengaruh Asupan Purin Dan Cairan Terhadap Kadar Asam Urat Wanita Usia 50-60 Tahun Di Kecamatan gajah Mungkur, Semarang. Journal of Nutrition College,2013, 2(1), 44-49

27. Chernoff, R. 2014.Geriatric Nutrition the Health Profesional's Hanbook Fourth Edition. Boston: Jones and Bartlett Publishers.

28. Meliny, Suhadi, Muhamad Sety. 2018. Analisis Faktor Risiko Rematik Usia 45-54 Tahun Di Wilayah Kerja Puskesmas Puuwatu Kota Kendari Tahun 2017. Jurnal Ilmiah Mahasiswa Kesehatan Masyarakat Vol-2/NO. 2/ April 2018; ISSN : 2502-73 IX. Pp1-7

29. Haryani Sulistyoningsih, Gizi untuk Kesehatn Ibu dan Anak, Graha Ilmu.

30. Ida Untari, Titin Wijayanti.2017. Hubungan Antara Pola Makan Dengan Penyakit Gout. The Urecol Proceeding. Yogyakarta. Diakses bulan Februari 2018. http://pp.uad.ac.id/wp-content/uploads/2017/05/92.-ida-untari-730735.pdf

31. Sri Sayekti. Hubungan Pola Makan Dengan Kadar Asam Urat Pada Pra Lansia Di Rt:02/Rw:02 Desa Candimulyo Kecamatan Jombang Kabupaten Jombang. Jurnal Insan Cendekia. Volume 6 No. 1 September 2017. Pp 9-19 DOI: https://doi.org/10.35874/jic.v6i1.324 